\title{
Aplikasi Pembelajaran Interaktif Pengenalan Hewan pada Anak Usia Dini
}

\author{
Nurul Maulida ${ }^{\# 1}$, Hengky Anra ${ }^{\# 2}$, Helen Sasty Pratiwi ${ }^{\# 3}$

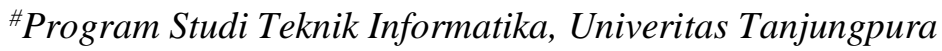 \\ Jl. Prof. Dr. H. Hadari Nawawi, Pontianak, Kalimantan Barat 78115 \\ 1nmaulida582@gmail.com \\ ${ }^{2}$ hengkyanra@informatika.untan.ac.id \\ ${ }^{3}$ helensastypratiwi@informatika.untan.ac.id
}

\begin{abstract}
Abstrak - Pada Anak usia dini umur 0-6 tahun berada di masa peka. Masa seluruh potensi dapat dikembangkan secara optimal dalam aspek fisik, bahasa, kognitif. Kemampuan membaca berhubungan aktivitas membaca, pada anak usia dini membaca membutuhkan berbagai stimulasi. Stimulasi diberikan melalui media pembelajaran dalam pengenalan makhluk hidup yang disekitar. Aplikasi teknologi berbasis komputer dalam pembelajaran dikenal sebagai Computer Assisted Instruction (CAI). CAI atau pembelajaran berbantuan komputer merupakan pengembangan dari teknologi informasi terpadu yaitu komunikasi (interaktif), audio, video, penampilan citra (image) yang dikemas dengan sebutan teknologi multimedia. Tujuan penelitian ini adalah menghasilkan aplikasi yang memanfaatkan teknologi multimedia dengan konsep CAI untuk anak usia dini dalam. Metode yang digunakan dalam penelitian ini adalah research and development (penelitian dan pengembangan) yaitu metode penelitian yang digunakan untuk menghasilkan produk tertentu dan menguji ke efektifan produk. Hasil yang didapatkan dari uji coba dan validasi menggunakan skala guttman dari sisi materi dengan nilai koefisien reabilitas $=1$ dan koefisien skalabilitas 1 , dari sisi multimedia nilai koefisien reabilitas $=1$ dan koefisien skalabilitas 1 , dari sisi CAI nilai koefisien reabilitas $=1$ dan koefisien skalabilitas 1 , yang berarti aplikasi ini layak menjadi media pembelajaran dan sudah memenuhi sebagai kriteria aplikasi CAI berbasis multimedia yang ditunjukan untuk anak usia dini dengan usia 5-6 dalam mengenal hewan dengan konsep tutorial dan game.
\end{abstract}

Kata Kunci: Pendidikan Anak Usia Dini, bahasa, Computer Assisted Instruction (CAI), Research and development, skala guttman

\section{PENDAHULUAN}

Pendidikan Anak Usia Dini (PAUD) adalah suatu upaya pembinaan yang ditujukan kepada anak sejak lahir sampai pada usia enam tahun yang dilakukan dengan memberikan rangsangan pendidikan untuk membantu perkembangan jasmani dan rohani agar anak memiliki kesiapan dalam memasuki pendidikan lebih lanjut[1].

Masa usia 0-6 tahun anak perlu mendapatkan stimulasi yang tepat agar seluruh aspek perkembangan anak dapat berkembang optimal, baik aspek kognitif, bahasa, fisikmotorik, moral agama maupun aspek sosial emosionalnya [2]. Kelima aspek perkembangan tersebut tidak dapat dipisahkan satu dengan yang lainnya. Meskipun demikian bahasa memiliki peran yang sangat penting dalam tumbuh kembang anak terutama dalam membantu seseorang untuk berinteraksi dan berkomunikasi dengan orang lain.

Pengelompokkan pengembangan bahasa menjadi dua yaitu; mendengar dan berbicara, serta membaca dan menulis [3]. Terdapat dua daerah pertumbuhan bahasa yaitu bahasa yang bersifat pengertian atau reseptif yang meliputi mendengar dan membaca; serta bahasa yang bersifat pernyataan atau ekspresif yang meliputi berbicara dan menulis [4].

Pada tahap membaca untuk anak usia dini membutuhkan berbagai stimulasi untuk membaca dan mengeja, misalnya saja pengetahuan tentang huruf-huruf alfabet, berbagai gambar yang menarik untuk menstimulasi anak mengenal simbol-simbol dan lain sebagainya. Stimulasi dapat mulai diberikan melalui hal - hal yang biasa anak temui salah satunya adalah makhluk hidup yang ada disekitar.

Dalam pengenalam hewan tersebut dibutuhkan sebuah metodologi pembelajaran ada dua aspek yang amat penting yaitu model pembelajaran dan media pembelajaran [6] Melalui pemilihan media pembelajaran yang tepat, hal-hal yang abstrak dapat di kongkretkan. Media pembelajaran berbasis komputer atau CAI (Computer Assisted Intruction) paling sering digunakan. 
Pembelajaran CAI dalam pembelajaran dapat meningkatkan pemahaman konsep dan movtivasi belajar. Selain itu juga dapat menghubungkan dan memperkuat teori, meningkatkan antusiasme belajar anak melalui interaktivitas, meningkatkan kemampuan teknologi informasi dan mampu memberikan umpan balik [7].

Berdasarkan latar belakang tersebut maka muncul gagasan untuk membuat aplikasi pembelajaran interaktif (CAI) dalam mengenal hewan pada anak usia dini. Model pembelajaran yang akan disampaikan ini adalah model tutorial dan bermain sehingga anak usia dini dapat belajar secara bertahap dan dapat mengevaluasi hasil pembelajaran dengan model bermain.

\section{URAIAN PENELITIAN}

\section{A. Hakikat Anak Usia Dini}

Anak usia dini adalah anak yang berada pada rentan usia 0-6 tahun (UU tahun 2003, tentang Sisdiknas. Anak usia dini adalah kelompok anak yang berada dalam proses pertumbuhan dan perkembangan yang bersifat unik [8]. Pada masa ini merupakan masa emas atau golden age, karena anak mengalami pertumbuhan dan perkembangan yang sangat pesat dan tidak tergantikan pada masa mendatang. Pendidikan anak usia dini harus berlandaskan pada kebutuhan anak, yang disesuaikan dengan nilai-nilai yang dianut di lingkungan di sekitarnya, sesuai dengan tahap perkembangan fisik dan psikologis anak, dilaksanakan dalam suasana bermain yang menyenangkan serta dirancang untuk mengoptimalkan potensi anak.

\section{B. Pembelajaran Berbantuan Komputer Atau Computer Assisted Instruction (CAI)}

Istilah pembelajaran berbantuan komputer diterjemahkan dari CAI (Computer-Assisted Instruction), sering juga digunakan secara bergantian dengan istilah CBL (ComputerBased Learning) dan CBI (Computer-Based Instruction) [8]. Pembelajaran berbasis computer (Computer Based Instruction) menunjuk pada semua software pendidikan yang diakses melalui komputer dimana siswa dapat berinteraksi dengannya, salah satunya multimedia interaktif. Sistem komputer menyajikan serangkaian program pengajaran kepada siswa baik berupa informasi maupun latihan soal untuk mencapai tujuan pembelajaran tertentu dan siswa melakukan aktivitas belajar dengan cara berinteraksi dengan sistem komputer.

Model pembelajaran yang diterapkan dalam pembelajaran berbantuan komputer secara umum, yaitu [9] :

1. Model Tutorial (Penjelasan)

Model tutorial adalah program yang didesain untuk berperan sebagai tutor bagi siswa. Model tutorial berisi konsep, penjelasan, rumus-rumus, prinsip, bagan, tabel, definisi, istilah dan latihan.

2. Model Drill and Practice (Latihan dan Praktek)

Model drill and practice didasarkan pada asumsi bahwa konsep-konsep dasar yang telah dikuasai oleh siswa dapat digunakan untuk menerapkan rumus-rumus, bekerja dengan kasus-kasus konkret, dan menjelajahi daya tangkap mereka tentang materi.

3. Model Simulation (Simulasi)

Model simulasi adalah suatu gambaran atau model dari peristiwa, objek atau beberapa fenomena yang disederhanakan yang meliputi unsur - unsur penting.

4. Model Game (Permainan)

Model game adalah model pembelajaran yang didapatkan dari hasil bermain sebuah game.

\section{Membaca}

Membaca merupakan salah satu dari empat keterampilan berbahasa yang diajarkan di sekolah. lingkungan, pencegah bahaya kebakaran, serta piranti keamanan fisik. Kegiatan membaca merupakan kegiatan yang bersifat reseptif. Kegiatan ini disejajarkan dengan kegiatan menyimak atau mendengarkan. Membaca adalah suatu kegiatan fisik dan mental [10].

Istilah yang sering digunakan dalam komponen dasar dari proses membaca, yaitu recording, decoding, dan meaning. Recording merujuk pada katakata dan kalimat, sedangkan proses decoding (penyandian) merujuk pada proses penerjemahan rangkaian grafis ke dalam kata-kata. Sementara itu proses memahami makna (meaning) berlangsung melalui berbagai tingkat, mulai dari tingkat pemahaman literal sampai kepada pemahaman interpretatif, kreatif, dan evaluatif.

\section{Metode Penelitian Dan Pengembangan (Research And Development)}

Metode penelitian dan pengembangan atau dalam bahasa Inggrisnya Research and Development adalah metode penelitian yang digunakan untuk menghasilkan produk tertentu dan menguji kefektifan produk tersebut Metode penelitian dan pengembangan telah banyak digunakan pada bidang-bidang ilmu alam dan teknik. Hampir semua produk teknologi diproduksi dan dikembangkan melalui metode penelitian dan pengembangan. Namun demikian, metode penelitian dan pengembangan bisa juga digunakan dalam bidang ilmu-ilmu sosial [11].

\section{E. Skala Guttman}

Skala Guttman dikembangkan oleh Louis Guttman. Skala ini mempunyai ciri penting, yaitu merupakan skala kumulatif dan mengukur satu dimensi saja dari satu variabel yang multi dimensi, sehingga skala ini termasuk mempunyai sifat undimensional. Skala Guttman yang disebut juga metode scalogram atau analisa skala (scale analysis) sangat baik untuk menyakinkan peneliti tentang kesatuan dimensi dari sikap atau sifat yang diteliti, yang sering disebut isi universal (universe of content) atau atribut universal (universe attribute. Skala Guttman merupakan skala pengukuran yang mempunyai jawaban tegas yaitu "ya-tidak", "benar-salah", "positifnegatif", dan lain-lain. 
Menurut metode survey rumus yang cocok untuk uji validitas dengan skala Guttman yaitu rumus koefisien reprodusibilitas dan koefisien skalabilitas sehingga terlebih dahulu kita harus menghitung koefisien reprodusibilitas dan selanjutnya koefisien skalabilitasnya secara berurutan [12].

\section{Rumus Koefisien Reprodusibilitas \\ $\mathrm{Kr}=\mathbf{1 - ( e / n )}$ \\ Keterangan: \\ e $=$ jumlah kesalahan/nilai error \\ $\mathrm{n}=$ jumlah pernyataan dikali jumlah responden \\ (1)}

Syarat penerimaan nilai koefisien reprodusibiltas yaitu apabila koefisien reprodusibiltas memiliki nilai $>0,90$.

\section{Rumus Koefisien Skalabilitas \\ $\mathbf{K s}=\mathbf{1 -}(\mathbf{e} / \mathbf{x})$ \\ Keterangan: \\ $\mathrm{e}=$ jumlah kesalahan/nilai error \\ $\mathrm{x}=0,5(\{$ jumlah pernyataan dikali jumlah responden \} -jumlah jawaban "ya")}

Syarat penerimaan nilai koefisien skalabilitas yaitu apabila koefisien skalabilitas memiliki nilai $>0,60$.

F. Diagram Alir Penelitian

Langkah-langkah penelitian yang dilakukan seperti pada gambar. 1sebagai berikut

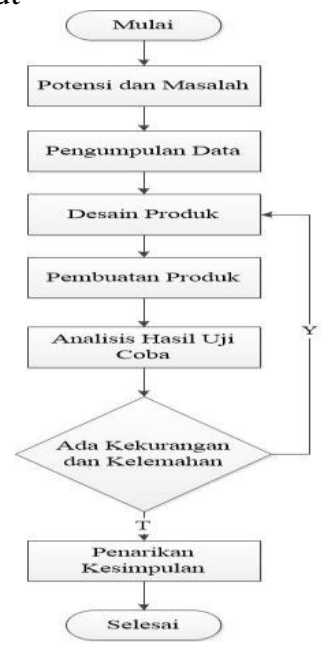

Gambar 1 Diagram Alir Penelitian

G. Flowchart Aplikasi

Flowchart (Bagan Alir) dibuat untuk menggambarkan urutan operasi pelaksanaan aplikasi. Flowchart aplikasi CAI berbasis multimedia untuk pengenalan bagian tubuh manusia pada anak usia dini terdapat pada ambar. 2 berikut ini.

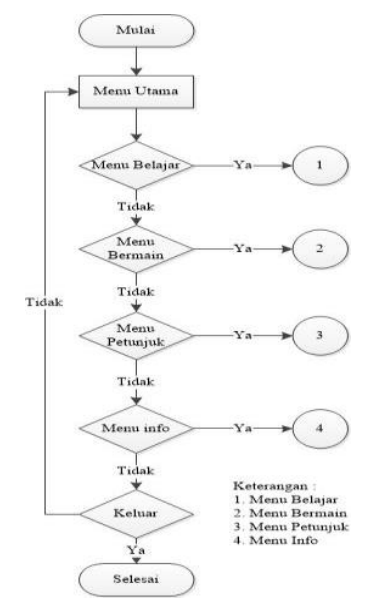

Gambar 2 Flowchart Menu Utama

Pada menu utama, menu yang akan ditampilkan berupa menu belajar, menu bermain, menu petujuk, menu info, keluar. Ketika memilih salah satu menu tersebut maka akan menampilkan menu berikutnya. Untuk menampilkan flowchart dari menu belajar dapat dilihat pada gambar 3 .

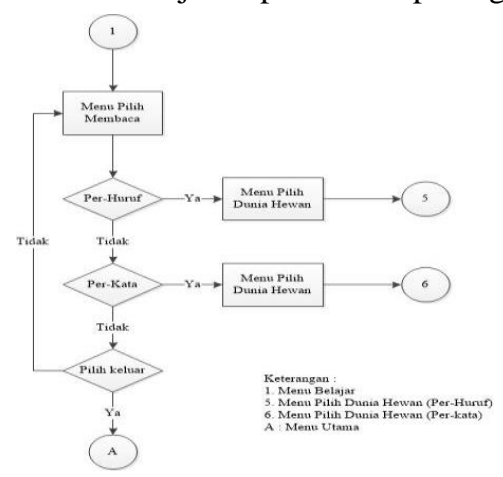

Gambar 3 Flowchart Menu Belajar

Pada flowchart menu belajar hanya menampilkan 2 katefori belajar yaitu belajar membaca per huruf dan belajar membaca perkata. Pada flowchart bermain, hanya menampilkan 2 kategori bermain yaitu bermain susun gambar dan bermain susun kata. Flowchart menu bermain dapat dilihat pada gambar 4 .

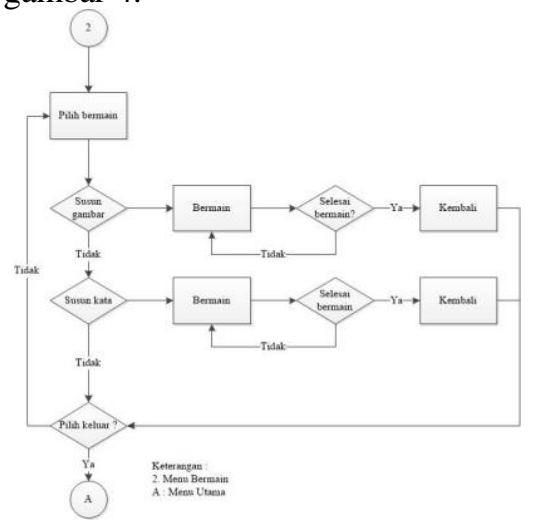




\section{Gambar 4 Flowchart Menu Bermain}

H. Storyboard Dan Perancangan Antarmuka

Storyboard perancangan antarmuka (interace) aplikasi dapat pada tabel dibawah ini.

Tabel 1. Storyboard Aplikasi dan Perancangan Antarmuka

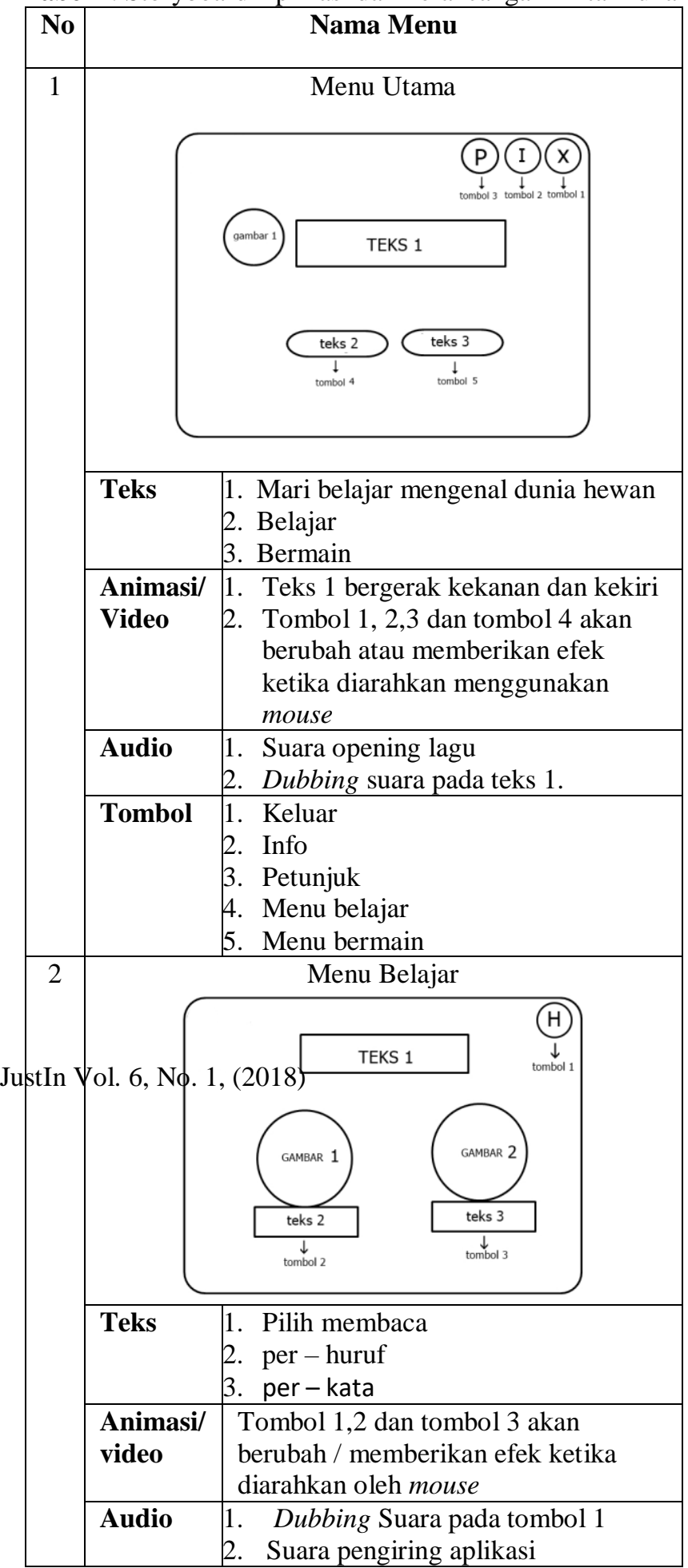

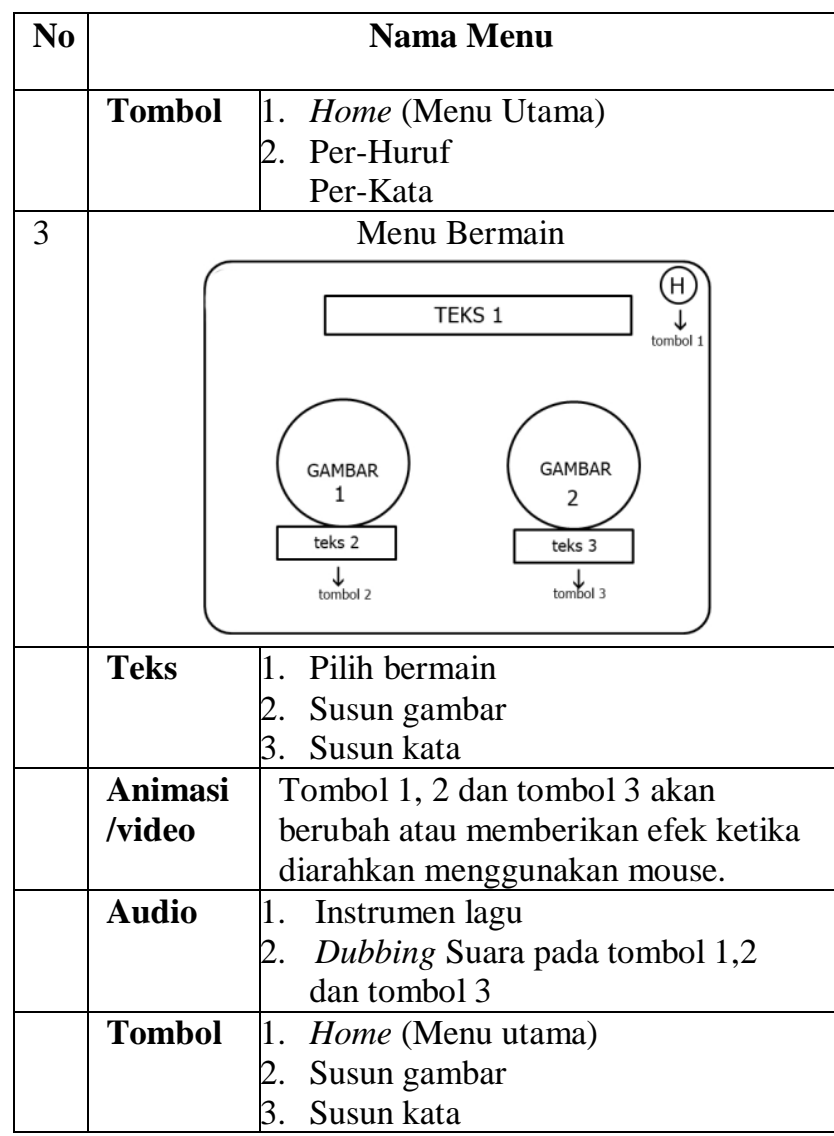

\section{HASIL DAN ANALISA}

\section{A. Implementasi Aplikasi}

Aplikasi CAI berbasis multimedia untuk pengenalan nama hewan yang telah dibuat dapat diimplementasikan pada laptop atau komputer (tanpa koneksi internet) dengan sistem operasi windows. File aplikasi ini dengan ekstensi .exe dapat dicopy pastekan dan langsung dimainkan dikomputer tanpa melalui proses instalasi. Komputer yang digunakan juga harus memiliki speaker agar user dapat mendengarkan suara ejaan nama hewan yang ditampilkan sekaligus dapat mendengarkan musik pengiring aplikasi tersebut.

Elemen atau objek-objek multimedia yang digunakan pada aplikasi ini adalah teks, gambar, bunyi, video, dan animasi. Sedangkan model CAI yang digunakan pada aplikasi ini adalah model turorial dan game. Tampilan menu utama aplikasi dapat dilihat pada Gambar.5 dan salah satu tampilan dari menu belajar dapat dilihat pada Gam 


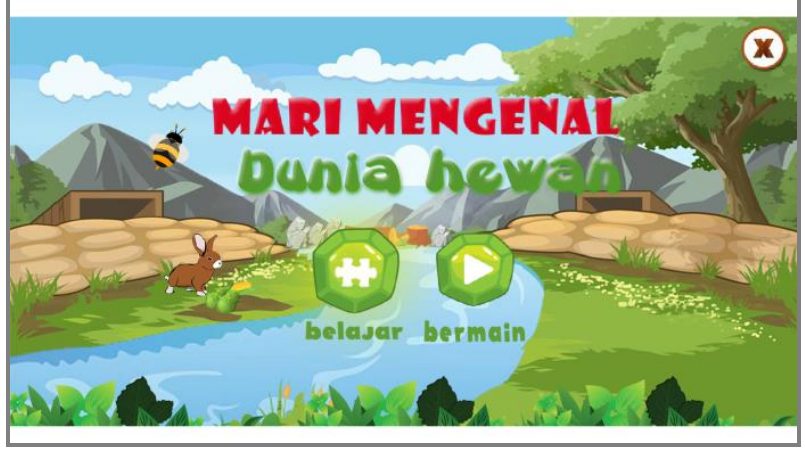

Gambar 5 Tampilan Menu Utama Aplikasi

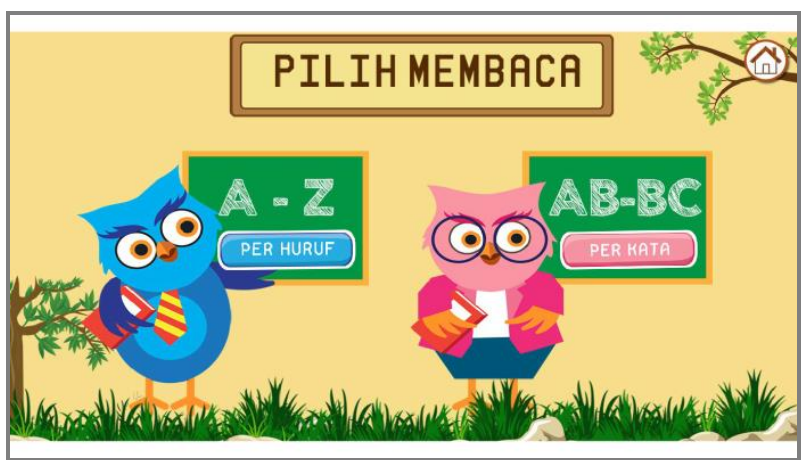

Gambar 6 Tampilan Menu Belajar

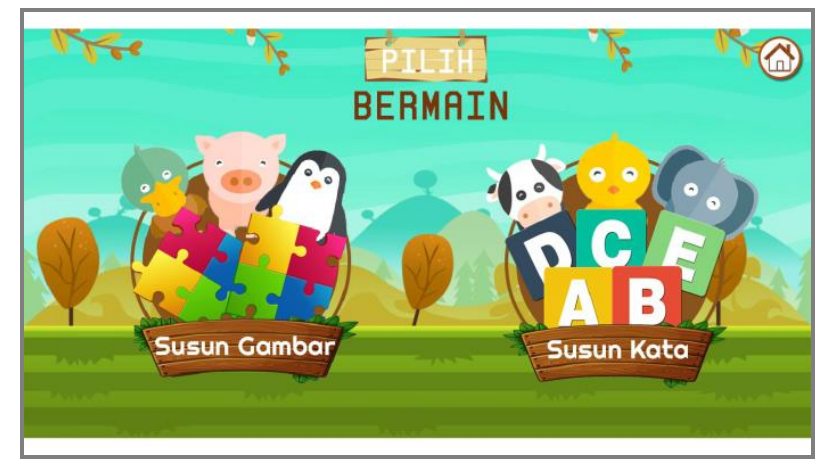

Gambar 7 Tampilan Menu Bermain

B. Analisisi Hasil Uji Coba dan Validasi Produk

Uji coba produk/aplikasi dilakukan oleh tiga orang ahli atau pakar sekaligus yang akan memvalidasi produk/aplikasi tersebut bertujuan untuk mengcek kelayakan aplikasi sebagai pembelajaran yang ditinjau dari 3 sisi yaitu, 1) Sisi Materi, 2) Sisi Multimedia, dan 3) sisi CAI. Uji coba aplikasi dilakukan menggunakan laptop/komputer yang tersedia. Aplikasi yang sudah siap digunakan ditunjukkan ke masing-masing ahli atau pakar yang akan menilai aplikasi tersebut sesuai dengan aspekaspek penilaian yang digunakan untuk menilai aplikasi tersebut.

Untuk Penggunaan aplikasi pada anak, penggunaan aplikasi dibimbing langsung oleh beberapa guru yang memahami penggunaan komputer. Agar tujuan dari pembelajaran tersebut tercapai, pada pengguna aplikasi tersebut. Anak-anak dapat memainkan aplikasi tersebut dengan baik, namun ada juga berberapa yang butuh arahan dalam penggunaan aplikasi tersebut.

Pada penelitian ini, skala pengukuran Guttman digunakan untuk validasi produk oleh pakar atau tenaga ahli yang akan menguji coba aplikasi yang telah dibuat. Berikut ini adalah analisis terhadap setiap hasil validasi:

1. Analisis hasil uji kevalidan dari sisi materi

Pada pengujian dari sisi materi dilakukan oleh guru yang memberi pelajaran dan menguasi aspek - aspek materi pembelajaran pada anak usia dini. Pada pengujian dari sisi materi diberikan sepuluh pertanyaa yang sesuai dengan aspek penilaian dalam pembelajaran, dimana pada setiap aspek tersebut terdapat indikator yang akan menilai apakah materi yang disajikan pada aplikasi tersebut layak dan sesuai. Berikut ini tabel hasil uji kevalidan sisi materi dapat dilihat pada tabel 2 .

Tabel 2. Tabel guttman uji kevalidan dari sisi Materi

\begin{tabular}{|c|c|c|c|c|c|c|c|}
\hline \multirow{2}{*}{ Responden } & \multicolumn{7}{|c|}{ Pertanyaan ke- } \\
\cline { 2 - 9 } & $(1)$ & $(2)$ & $(3)$ & $\ldots$ & $\ldots$ & $(9)$ & $(10)$ \\
\hline 1 & 1 & 1 & 1 & 1 & 1 & 1 & 1 \\
\hline
\end{tabular}

Keterangan :

$\mathrm{n}: 1 \times 10=10$

e : 0

$\mathrm{x}: 0,5(10-10)=0$

Pembahasan :

$$
\begin{aligned}
\mathrm{Kr} & =1-(\mathrm{e} / \mathrm{n}) \\
\mathrm{Kr} & =1-(0 / 10) \\
& =\mathbf{1} \\
\mathrm{Ks} & =1-(\mathrm{e} / \mathrm{x}) \\
\mathrm{Ks} & =1-(0 / 0,5(10-10)) \\
& =\mathbf{1}
\end{aligned}
$$

Dalam perhitungan ini dapat terlihat jika KR $>1$ dan KS > 1 sehingga dapat disimpulkan hasil perhitungan semua item pertanyaan (1-10) adalah valid.

\section{Analisis Hasil Uji Kevalidan dari Sisi Multimedia}

Pada pengujian dari sisi multimedia dilakukan oleh dosen FKIP PG-PAUD yang ahli multimedia yang mengajar mata kuliah yang berkaitan dengan multimedia. Pada pengujian dari sisi multimedia diberikan lima pertanyaa yang sesuai dengan aspek penilaian dalam sisi multimedia, dimana pada setiap aspek tersebut terdapat indikator yang akan menilai apakah sisi multimedia yang disajikan pada aplikasi tersebut layak dan sesuai. Berikut ini hasil uji kevalidan sisi multimedia dapat dilihat pada tabel 3 . 
Tabel 3. Tabel guttman uji kevalidan dari sisi Multimedia

\begin{tabular}{|c|c|c|c|c|c|}
\hline \multirow{2}{*}{ Responden } & \multicolumn{5}{|c|}{ Pertanyaan ke- } \\
\cline { 2 - 6 } & $(1)$ & $(2)$ & $(3)$ & $(4)$ & $(5)$ \\
\hline 1 & 1 & 1 & 1 & 1 & 1 \\
\hline
\end{tabular}

Keterangan :

$\mathrm{n}: 1 \times 5=5$

e : 0

$\mathrm{x}: 0,5(5-5)=0$

Pembahasan :

$\mathrm{Kr} \quad=1-(\mathrm{e} / \mathrm{n})$

$\mathrm{Kr} \quad=1-(0 / 5)$

$=1$

Ks $\quad=1-(\mathrm{e} / \mathrm{x})$

Ks $\quad=1-(0 / 0,5(5-5))$

$=1$

Dalam perhitungan ini dapat terlihat jika KR > 1 dan KS $>1$ sehingga dapat disimpulkan hasil perhitungan semua item pertanyaan (1-5) adalah valid.

\section{Analisis Hasil Uji Kevalidan Dari Sisi CAI}

Pada pengujian dari sisi CAI dilakukan oleh dosen Teknik Informatika ahli CAI yang memahami media pembelajaran berbasis CAI. Pada pengujian dari sisi CAI diberikan lima pertanyaan yang sesuai dengan aspek penilaian dalam CAI, dimana pada setiap aspek tersebut terdapat indikator yang akan menilai apakah sisi CAI yang disajikan pada aplikasi tersebut layak dan sesuai. Berikut ini tabel hasil uji kevalidan sisi materi dapat dilihat pada tabel 4.

\begin{tabular}{|c|c|c|c|c|c|}
\hline \multirow{2}{*}{ Responden } & \multicolumn{5}{|c|}{ Pertanyaan ke- } \\
\cline { 2 - 6 } & $(1)$ & $(2)$ & $(3)$ & $(4)$ & $(5)$ \\
\hline 1 & 1 & 1 & 1 & 1 & 1 \\
\hline
\end{tabular}

\section{Keterangan :}

$\mathrm{n}: 1 \times 5=5$

e : 0

$\mathrm{x}: 0,5(5-5)=0$

Pembahasan :

$\mathrm{Kr} \quad=1-(\mathrm{e} / \mathrm{n})$

$\mathrm{Kr} \quad=1-(0 / 5)$

$=1$

Ks $\quad=1-(\mathrm{e} / \mathrm{x})$

Ks $\quad=1-(0 / 0,5(5-5))$
$=1$

Dalam perhitungan ini dapat terlihat jika KR > 1 dan KS > 1 sehingga dapat disimpulkan hasil perhitungan semua item pertanyaan (1-5) adalah valid.

\section{A. Kesimpulan \\ IV.KESIMPULAN DAN SARAN \\ Berdasarkan hasil analisis uji coba dan validasi} terhadap aplikasi pembelajaran interaktif pada anak usia dini dalam mengenal hewan model bottom up, dapat disimpulkan bahwa :

1. Pemilihan kategori hewan dan penyajian materi sesuai dengan indikator pencapaian perkembangan dan sub tema pembelajaran pada anak usia dini.

2. Berdasarkan hasil validasi dengan menggunakan skala guttman pada sisi Ahli Materi, sisi Ahli dan sisi Ahli CAI tiap -tiap aspek penilaian mendapatkan nilai $\mathrm{Kr}=1$ dan $\mathrm{Ks}=1$ yang berarti aplikasi tersebut sudah memenuhi aspek-aspek yang berada pada CAI dan dapat diartikan bahwa aplikasi tersebut sudah berjalan dengan baik.

\section{B. Saran}

Hal- hal yang menjadi saran untuk penelitian dan pengembangan pada aplikasi ini agar menjadi lebih baik yaitu:

1. Penambahan materi pembelajaran yang sesuai dengan sub tema agar pembelajaran lebih bervariasi.

2. Mengembangkan aplikasi ke platform android sehingga aplikasi ini nantinya dapat dimainkan dismartphone atau tablet dengan sistem operasi android.

\section{DAFTAR PUSTAKA}

[1] Departemen Pendidikan Nasional, (2003). Undang-Undang Nomor 20 Tahun 2003, Tentang Sistem Pendidikan Nasional, Jakarta: Depdiknas.

[2] Ramli, M. (2005). Pendampingan Perkembangan Anak Usia Dini. Jakarta: Departemen Pendidikan Nasional.

[3] Bachri, B. (2005). Pengembangan Kegiatan Bercerita di Taman Kanakkanak, Teknik dan Prosesnya. Jakarta: Departemen Pendidikan Nasional.

[4] Patmonodewo, S. (2003). Pendidikan Anak Prasekolah. Jakarta : Rineka Cipta.

[5] Nana Sudjana, A. R. (2011). Media Pembelajaran. Bandung: Sinar Baru.

[6] Yuniarti, F. P. (2012). Pengembangan Virtual Laboratory Sebagai Media Pembelajaran Berbasis Komputer pada Meteri Pembiakan Virus. Unnes Journal of Biology Education .

[7] Mansur. (2005). Pendidikan Anak Usia Dini Dalam Islam. Yogyakarta: Pustaka Pelajar.

[8] Susilana, R. (2007). Media Pembelajaran. Bandung: CV. Wacana Prima.

[9] Patmonodewo, S. (2003). Pendidikan Anak Prasekolah. Jakarta : Rineka Cipta.

[10] Tampubolon. (1993). Mengembangkan Minat dan Kebiasaan Membaca Pada Anak. Bandung: Angkasa.

[11] Sugiyono. (2008). Metode Penelitian Kuantitatif Kualitatif dan R\&D. Bandung: Alfabeta.

[12]Priyatno, D. (2010). Teknik Mudah dan Cepat Melakukan Analisis Data Penelitian dengan SPSS dan Tanya Jawab Ujian Pendadaran. Yogyakarta: Gaya Media. 